\title{
Black Carbon Exposure Characteristics in Diesel Engine Vehicle-related Jobs
}

Aerosol and Air Quality Research

\section{OPEN ACCESS}

Received: December 30, 2020

Revised: May 5, 2021

Accepted: May 12, 2021

${ }^{*}$ Corresponding Author:

pdw545@gmail.com

${ }^{\dagger}$ These authors contributed equally to this work

\section{Publisher:}

Taiwan Association for Aerosol Research

ISSN: $1680-8584$ print

ISSN: 2071-1409 online

Copyright: The Author(s). This is an open access article distributed under the terms of the Creative Commons Attribution License (CC BY 4.0), which permits unrestricted use, distribution, and reproduction in any medium, provided the original author and source are cited.

\section{Sangjun Choi ${ }^{1+}$, Ju-Hyun Park ${ }^{2+}$, Won Kim ${ }^{3}$, Seung Won Kim ${ }^{4}$, Kyong-Hui Lee ${ }^{5}$, Taejin Chung ${ }^{6}$, Jihoon Park ${ }^{7}$, Seung-Hun Ryu ${ }^{8}$, Jungah Shin ${ }^{9}$, Dong-Hee Koh ${ }^{10}$, Dong-Uk Park ${ }^{11^{*}}$}

\author{
${ }^{1}$ Department of Preventive Medicine, College of Medicine, The Catholic University of Korea, \\ Seocho-gu, Seoul 06591, Korea \\ ${ }^{2}$ Department of Statistics, Dongguk University, Jung-gu, Seoul 04620, Korea \\ ${ }^{3}$ Wonjin Institute for Occupational and Environmental Health, Jungnang-gu, Seoul 02221, Korea \\ ${ }^{4}$ Department of Public Health, Keimyung University, Dalseo-gu, Daegu 42601, Korea \\ ${ }^{5}$ Force Health Protection \& Preventive Medicine, MEDDAC-Korea, Unit \#15281, US Army, APO \\ AP 96271, USA \\ ${ }^{6}$ Department of EHS Consulting, EHS Friends Co., Ltd., Bucheon-si, Gyeonggi-do 14446, Korea \\ ${ }^{7}$ Accident Response Coordination Division, National Institute of Chemical Safety, Ministry of \\ Environment, Heungdeok-gu, Cheongju 28164, Korea \\ ${ }^{8}$ Humidifier Disinfectant Health Center, National Institute of Environmental Research, Seogu, \\ Incheon 22689, Korea \\ ${ }^{9}$ Institute of Occupation and Environment, Korea Workers' Compensation and Welfare Service, \\ Bupyeong-gu, Incheon 21417, Korea \\ ${ }^{10}$ Department of Occupational and Environmental Medicine, International St. Mary's Hospital, \\ Catholic Kwandong University, Seo-gu, Incheon 22711, Korea \\ ${ }^{11}$ Department of Environmental Health, Korea National Open University, Jongro-gu, Seoul \\ 03087, Korea
}

\section{ABSTRACT}

We aimed to characterize the black carbon (BC) exposure from eight types of jobs involving diesel engine vehicles-namely, machinery operation, forklift operation, automobile assembly, garbage collection, garbage truck driving, delivery, toll operation, and crane operation-across seven industries. The workers chosen for this study $(N=106)$ measured their exposure every minute using an AE51 microAethalometer affixed to a microcyclone and also recorded their timeactivity patterns and whereabouts in detail during working hours. We then categorized and analyzed 71,987 of these 1-min observations based on four potential exposure determinants: the operation of a diesel engine vehicle (yes or no), proximity to the source of BC (near or far), location of the workplace (indoor or outdoor), and type of work (moving or stationary). Among the participants, the geometric mean (GM) exposure was highest for forklift operators in indoor environments $\left(9.5 \mu \mathrm{g} \mathrm{m}^{-3}\right)$, followed by toll operators $\left(\mathrm{GM}=7.4 \mu \mathrm{g} \mathrm{m}^{-3}\right)$, machinery operators $\left(\mathrm{GM}=7.4 \mu \mathrm{g} \mathrm{m}^{-3}\right)$, and garbage collectors $\left(\mathrm{GM}=5.5 \mu \mathrm{g} \mathrm{m}^{-3}\right)$. After accounting for the random effects of the individual workers and working dates (evaluated per occupation) as well as the fixed effects of the determinants and their pairwise interaction terms $(p<0.001)$, we found that all four of the determinants significantly differed in their associated levels of BC exposure. In particular, working near instead of far from diesel engine equipment doubled the average level of exposure. Additionally, upon investigating different combinations of the determinants, we identified proximity to diesel exhaust sources and indoor working conditions as the main factors of BC exposure. Thus, installing diesel particulate filters on diesel engine vehicles effectively reduces exposure. Our findings potentially contribute to the development of a model that predicts the level of exposure for various types of jobs.

Keywords: Black carbon, Determinant, Diesel engine exhaust emissions, Diesel particulate filter 


\section{INTRODUCTION}

Exposure to diesel engine exhaust emissions (DE) can occur in most industrial operations, jobs, and tasks where vehicles equipped with diesel engines are used, including trucks, vessels, cranes, and lifting or other machinery. Aside from the drivers who operate the diesel vehicles, the workers who assist or work alongside them can also be exposed to DE. All motorized transport using diesel fuel are considered important sources of black carbon (BC). BC has been used as an indicator of exposure to $D E$ because of its relevance to health and the availability of suitable measurement devices (HEI, 2010; Janssen et al., 2011). BC consists of pure carbon formed through the incomplete combustion of fossil fuels, biofuel, and biomass, and it is emitted in both anthropogenic and naturally occurring soot (Anenberg et al., 2012).

Several epidemiological studies have shown that the airborne BC mass concentration affects the morbidity and mortality of cardiovascular diseases (Zanobetti et al., 2013; Gong et al., 2019) and respiratory diseases (Hua et al., 2014) and causes decreased lung function (Suglia et al., 2008; Shakya et al., 2016; Paunescu et al., 2019).

The main sources of BC are combustion engines (especially diesel), residential burning of wood and coal, power stations using heavy oil or coal, and burning of agricultural wastes, as well as forest, smoking, and vegetation fires (WHO, 2012). The emission factor of fine particulates for diesel engine vehicles is much higher than that of gasoline engine vehicles (Yang et al., 2019). Emissions from vehicles and vessels with diesel engines contain higher levels of $B C$ than those from other sources. The transportation category is regarded as the main source of BC emissions in the United States and Western Europe (Grahame et al., 2014). Within this category, BC emissions from present-day diesel engines are more than eight times higher than those from gasoline-powered mobile sources in the United States (U.S. EPA, 2012).

Several studies have reported an increased occupational exposure to BC in a large group of workers, including municipal household garbage collectors (Lee et al., 2015), traffic police (Shakya et al., 2016), underground tunnel construction workers (Galea et al., 2016), farmers (Stapleton et al., 2018; Sauvé et al., 2020), subway workers (Choi et al., 2019) and toll operators (Shin et al., 2021). According to these studies, BC exposure levels were high when working with dieselpowered equipment indoors such as underground tunnels or subways. Underground tunnel construction workers showed the highest BC exposure level with the geometric mean (GM) concentration of $54 \mu \mathrm{g} \mathrm{m}^{-3}$ during sprayed concrete lining activities in the tunnel. Among subway workers, maintenance engineers who grind rails using diesel-powered motor cars had the highest exposure to $\mathrm{BC}\left(\mathrm{GM}=42.5 \mu \mathrm{g} \mathrm{m}^{-3}\right)$, whereas garbage collectors $\left(\mathrm{GM}=9.1 \mu \mathrm{g} \mathrm{m}^{-3}\right)$, traffic police (12-28 $\mu \mathrm{g} \mathrm{m}^{-3}$ ), farmers (daily $\mathrm{GM}=0.1-2.3 \mu \mathrm{g} \mathrm{m}^{-3}$ ) and toll operators ( $\mathrm{GM}$ in the booth $=7.3-$ $8.8 \mu \mathrm{g} \mathrm{m}^{-3}$ ) working outdoors had relatively low levels.

From these previous studies, it is possible to predict occupational BC exposure levels by using determinants such as indoor work and proximity to diesel-powered equipment. Workers involved in various types of jobs that operate diesel-powered vehicles or work in proximity to them can have varied exposure profiles even though they are working in the same work environment. However, no studies have compared BC exposure levels between various occupational groups using determinants.

Therefore, the objectives of this study were to assess the daily BC exposure of workers performing various jobs and activities involving diesel vehicles and to characterize major tasks and determinants that can influence $\mathrm{BC}$ exposure.

\section{METHODS}

\subsection{Description of Jobs Involving Diesel Vehicles}

Jobs and tasks by industry are briefly described in Table 1. A total of seven industries that include several jobs or operations involving diesel vehicles were classified into subclasses according to the Korean Standard Industrial Classification (KSIC) $10^{\text {th }}$ revision. The subclasses are indicated by a 5-digit coding system that classifies companies based on their business activities. Workplace photos for each job group are presented in Fig. S1. For the machine operators and automobile assemblers, the photos were not available due to confidentiality reasons. 


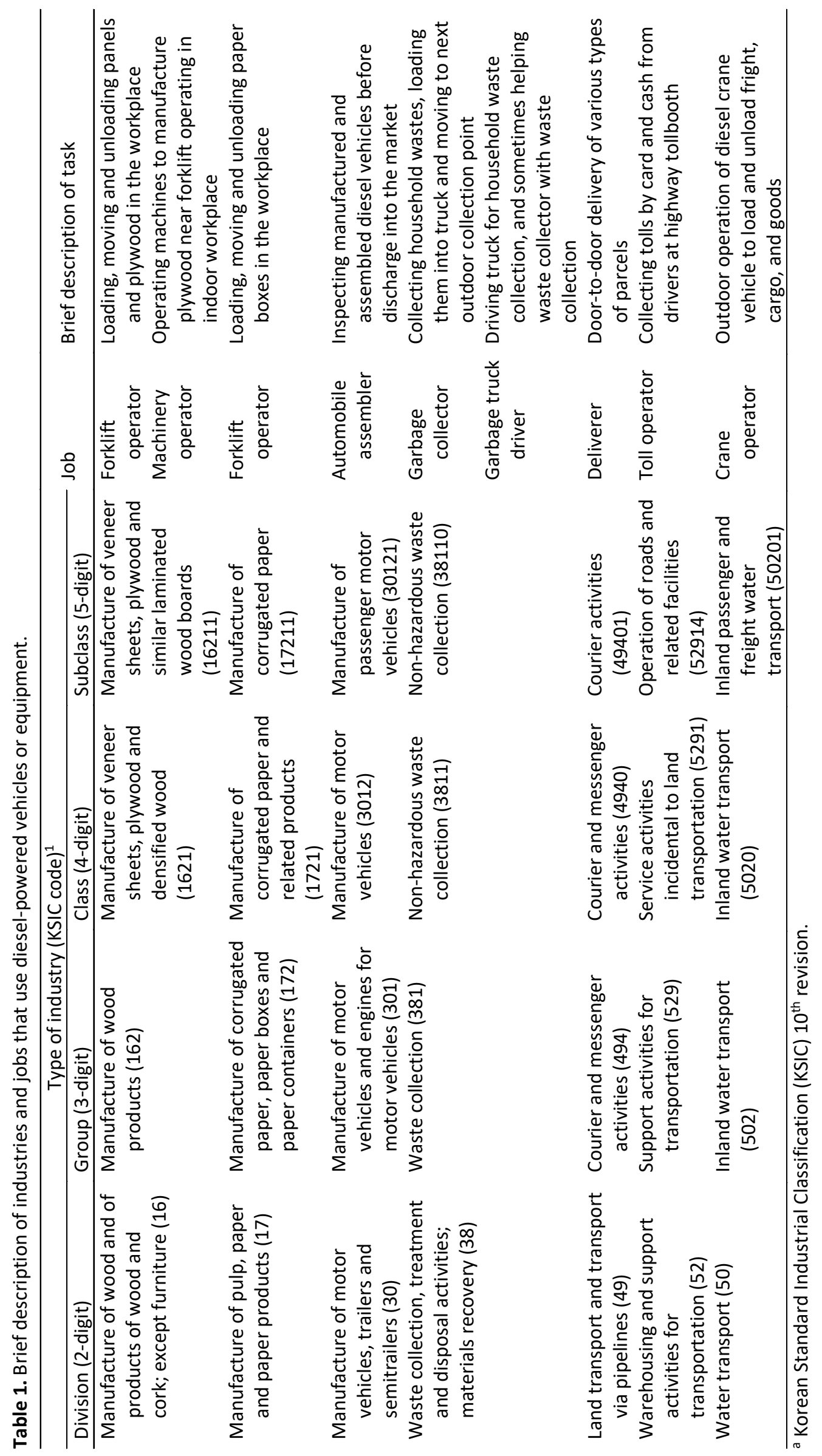




\subsection{BC Exposure Assessment Strategy}

A total of 106 workers from seven industries were invited to measure their exposure to $B C$. $A$ portable microAethalometer (Model AE51; AethLab Corp., San Francisco, CA, USA) was used to monitor the ambient $B C$ mass concentration, which served as a proxy for inhaled $B C$ particles or exposure to BC. This instrument can determine BC mass concentrations by detecting the difference in attenuation of light at $880 \mathrm{~nm}$ by particles collected on a filter at a given sampling interval (Lee, 2019). Being small (280 g) and portable, it can monitor personal exposure directly as workers move through activity spaces with varying concentrations of BC (Steinle et al., 2013; Dons et al., 2014). The flow rate was set at $100 \mathrm{~mL} \mathrm{~min}^{-1}$ with a sampling time of 1 minute. The filter strips were replaced before sampling to minimize the filter loading effect.

$\mathrm{BC}$ measurements were recorded every minute during working hours. Workers were provided with a waist pouch to carry the microAethalometer, and a tube was exposed to the air near the breathing zone. For workers who were more involved in manual labor, such as forklift operators, garbage collectors, deliverers, and automobile assemblers, the measuring device was put on the vest to prevent detection of vibration due to motion as much as possible. They were given detailed instructions to wear it as much as possible throughout working hours while performing their regular work activities. Personal $\mathrm{BC}$ samplers were not worn by crane operators because the time for workers to operate the cranes was not arranged in advance, making it difficult for the samplers to be worn. Instead, they were placed in the cabin near the driver's seat to estimate BC exposure. To test the precision of the monitoring, inter-comparison of the four microAethalometers was performed. Before field measurement, to ensure accuracy and precision, the devices were set at a pump rate of $150 \mathrm{~mL} \mathrm{~min}^{-1}$ and placed in the laboratory for 1 hour away from windows as well as combustion sources. The results showed that all devices were well correlated $(r>0.96)$. In the event of rain during the field investigation period, the measurement was stopped to reduce the effect of rapid humidity changes (Cai et al., 2014).

Workers were requested to write a time-activity diary (TAD) to match the levels of BC with the work activities they performed as well as their locations. After sampling, the TAD was completed by the workers with the help of an investigator. Information registered in the TAD included the start and end times for each work activity, as well as the locations they visited or stayed in. BC measurements monitored during direct smoking or in indirect smoking areas were excluded because they were not from a source of DE. The accuracies of the recorded activities and trips were checked by logging BC levels. Once monitoring during working hours was completed, followup interviews were administered to the workers in person to gain more accurate information on the activities which they performed.

\subsection{Data Analysis}

\subsubsection{Data preparation}

After each sampling session, real-time BC measurements were downloaded immediately to minimize data handling errors or recall bias. All data showing error code were excluded to maintain data integrity. $\mathrm{BC}$ data were right-skewed in a probability plot, indicating frequent occurrence of peak exposures. Consequently, the BC data were natural log-transformed for statistical analysis to make them more normally distributed. Negative measurements $(N=262,0.36 \%$ ) were included in the analysis by substituting the detection limit value of $0.001 \mu \mathrm{g} \mathrm{m}^{-3}$ because they were offset in subsequent observation(s) as Aethalometers computed the difference from previous measurements (McBean and Rovers, 1998; Dons et al., 2011). A total of 71,987 observations on a 1-min timescale were included in this study.

To identify the activities that contribute to $\mathrm{BC}$ exposure, all $\mathrm{BC}$ records were broadly categorized based on several potential BC exposure-related factors: type of industry, type of job, work activity, type of diesel vehicle, type of European emission standard (EURO Stage), and location of vehicle work. The TADs were used to annotate each 1-min BC exposure data file with the following four exposure determinants: operation of diesel engine vehicle (yes or no), proximity to source of BC (near or far), workplace (indoor or outdoor), and work type (moving or stationary).

\subsubsection{Statistical analysis}

$\mathrm{BC}$ exposure levels were summarized by a box plot and descriptive statistics were taken, which 
included the number of workers monitored, total number of measurements, arithmetic mean (AM), standard deviation (SD), GM, geometric SD (GSD), and minimum and maximum BC concentration. The two whiskers of the box plot extend to the $2.5^{\text {th }}$ and $97.5^{\text {th }}$ percentiles of the empirical distribution of $\mathrm{BC}$ measurements.

Since the industry, job, task, diesel particulate filter (DPF) installation, production year of diesel vehicles (or EURO Stage), and the four exposure determinants considered were expected to affect $\mathrm{BC}$ exposure levels, they were used as a basis for the classification. For each or a combination of factors, $95 \%$ confidence intervals were computed for both the AMs and GMs. A likelihood ratio test was conducted to compare the GM of BC exposure levels. Since it is likely that there existed a substantial correlation due to 1-min measurements repeatedly monitored on the same worker for a given date, a corresponding covariance component should be appropriately accounted for, and thus a linear mixed model was implemented for the likelihood ratio test. All statistical analyses were performed using R version 3.6.1 (R Foundation for Statistical Computing, Vienna, Austria) and all figures were drawn with Sigma Plot for Windows version 12.5 (Systat Software, San Jose, CA, USA).

\section{RESULTS AND DISCUSSION}

\subsection{BC Exposure Levels by Industry and Job}

The number of measurements and the distribution of $\mathrm{BC}$ mass concentrations by industry, and job are indicated in Table 2, Figs. 1, and 2. Diurnal exposure pattern of the BC exposure by job within 1 working day is presented in Fig. S2.

Significant differences in $B C$ mean exposure among the types of jobs within the industry were found $(p<0.001)$. Machinery operators $\left(\mathrm{AM}=13.0 \mu \mathrm{g} \mathrm{m}^{-3}, \mathrm{GM}=7.4 \mu \mathrm{g} \mathrm{m}^{-3}\right)$ in indoor workplaces showed the highest average $\mathrm{BC}$ exposure, followed by forklift operators in the manufacture of corrugated paper ( $\left.\mathrm{AM}=12.5 \mu \mathrm{g} \mathrm{m}^{-3}, \mathrm{GM}=7.5 \mu \mathrm{g} \mathrm{m}^{-3}\right)$; garbage collectors $\left(\mathrm{AM}=10.7 \mu \mathrm{g} \mathrm{m}^{-3}\right.$, $\mathrm{GM}=5.5 \mu \mathrm{g} \mathrm{m}^{-3}$ ); forklift operators in the manufacture of veneer sheets, plywood, and similar laminated wood boards $\left(\mathrm{AM}=10.7 \mu \mathrm{g} \mathrm{m}^{-3}, \mathrm{GM}=4.8 \mu \mathrm{g} \mathrm{m}^{-3}\right)$; and toll operators $\left(\mathrm{AM}=9.5 \mu \mathrm{g} \mathrm{m}^{-3}\right.$, $\mathrm{GM}=7.5 \mu \mathrm{g} \mathrm{m}^{-3}$ ) (Table 2).

Machine operators in the plywood manufacturing industry (KSIC code: 16211) worked in a stationary workplace indoors. They had the highest $B C$ exposure levels $\left(A M=13.0 \mu \mathrm{g} \mathrm{m}^{-3}\right.$ ) even though they did not directly handle diesel engine equipment. Near machine operation, forklifts are frequently operated to supply plywood raw materials for processing and moving the processed products. In Fig. S2(a), we can see a pattern of a periodic increase in the BC exposure levels of machine operators. There was no mechanical ventilation system inside the workplace, and natural ventilation was performed through the entrance inside the workplace. Therefore, the BC exposure level of a machine operator working in a fixed position indoors was higher than that of a forklift operator working while moving between indoor and outdoor workplaces (Fig. S1(a)).

While forklift operators in a plywood factory worked indoors and outdoors (Fig. S1(a)), forklift operators in a corrugated paper manufacturing factory (KSIC code: 17211) mostly moved boxes indoors. Therefore, the average $\mathrm{BC}$ exposures of forklift operators in the corrugated manufacturing factory $\left(\mathrm{AM}=14.7 \mu \mathrm{g} \mathrm{m}^{-3}, \mathrm{GM}=9.5 \mu \mathrm{g} \mathrm{m}^{-3}\right.$ ) were higher than those in the plywood factory (AM $=10.7 \mu \mathrm{g} \mathrm{m}^{-3}, \mathrm{GM}=4.8 \mu \mathrm{g} \mathrm{m}^{-3}$ ).

The average $\mathrm{BC}$ exposures of forklift operators and machinery operators were found to be higher than the averages monitored in subway environments. Choi et al. (2019) assessed BC exposure among types of subway workers in South Korea ( $N=61$; maintenance engineers: $A M=9.3 \mu \mathrm{g} \mathrm{m}^{-3}$, train drivers: $A M=5.9 \mu \mathrm{g} \mathrm{m}^{-3}$, subway station managers: $A M=2.2 \mu \mathrm{g} \mathrm{m}^{-3}$ ). In underground subway stations in New York City, the mean real-time BC concentrations ranged from 5 to $23 \mu \mathrm{g} \mathrm{m}^{-3}$ (Vilcassim et al., 2014). The main source of BC in the subway environment is likely to be dieselpowered trains operated for underground tunnel maintenance during the night, which is a likely cause for the build-up of BC levels in subway system air (Vilcassim et al., 2014; Choi et al., 2019). The BC exposures in the current study were far lower than the BC exposure concentrations (GM $=18-54 \mu \mathrm{g} \mathrm{m}^{-3}$ ) of workers involved in sprayed concrete lining activities for constructing an underground metro railway tunnel in London (Galea et al., 2016). Overall, high levels of BC have been reported in indoor workplaces, underground construction tunnels, subway tunnels, mining, 


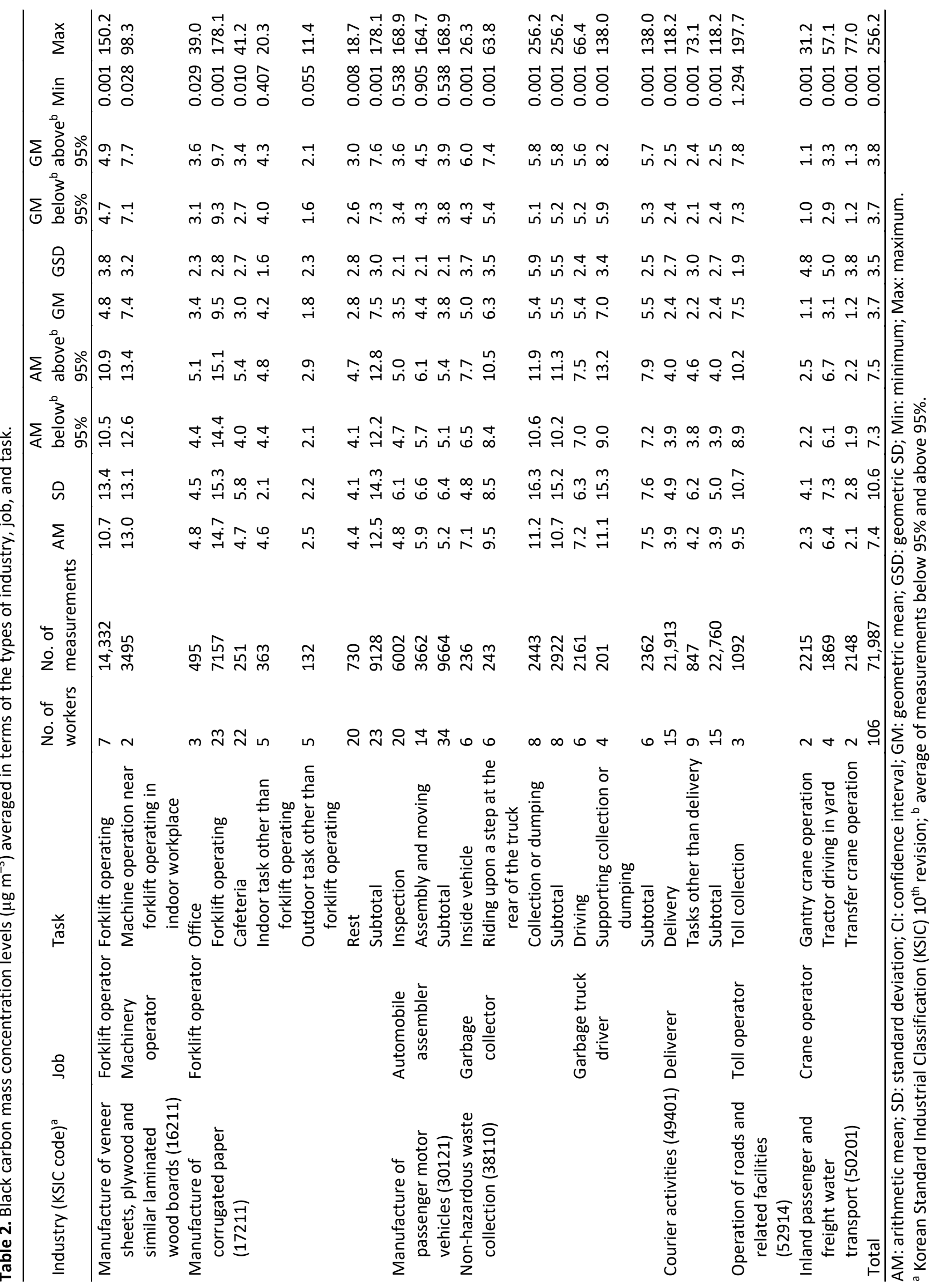




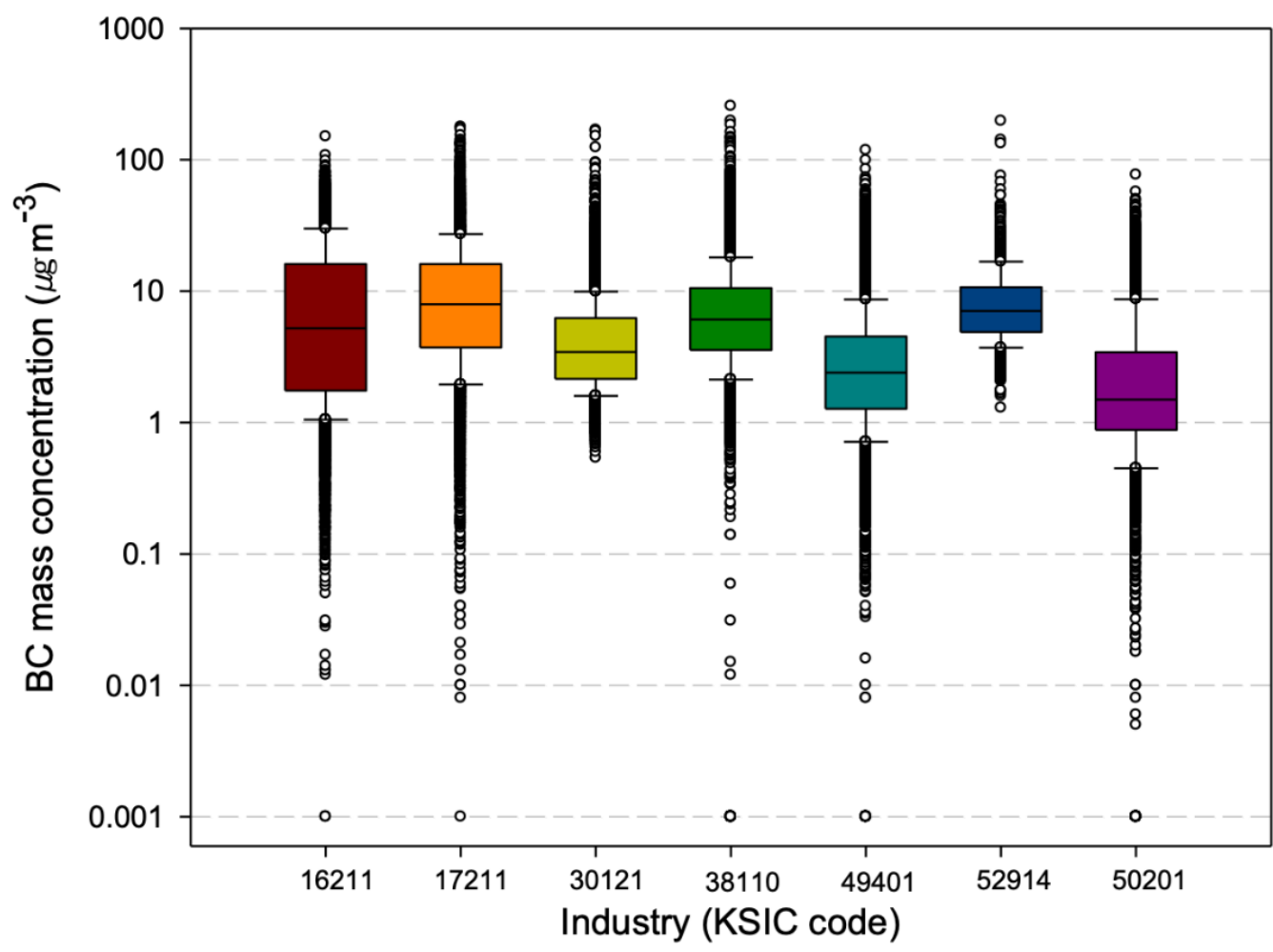

Fig. 1. Distribution of black carbon mass concentration levels among industries. Five-digit numbers indicate the Korean Standard Industrial code (16211: Manufacture of veneer sheets, plywood and similar laminated wood boards; 17211: Manufacture of corrugated paper; 30121: Manufacture of passenger motor vehicles; 38110: Non-hazardous waste collection; 49401: Courier activities; 52914: Operation of roads and related facilities; 50201: Inland passenger and freight water transport).

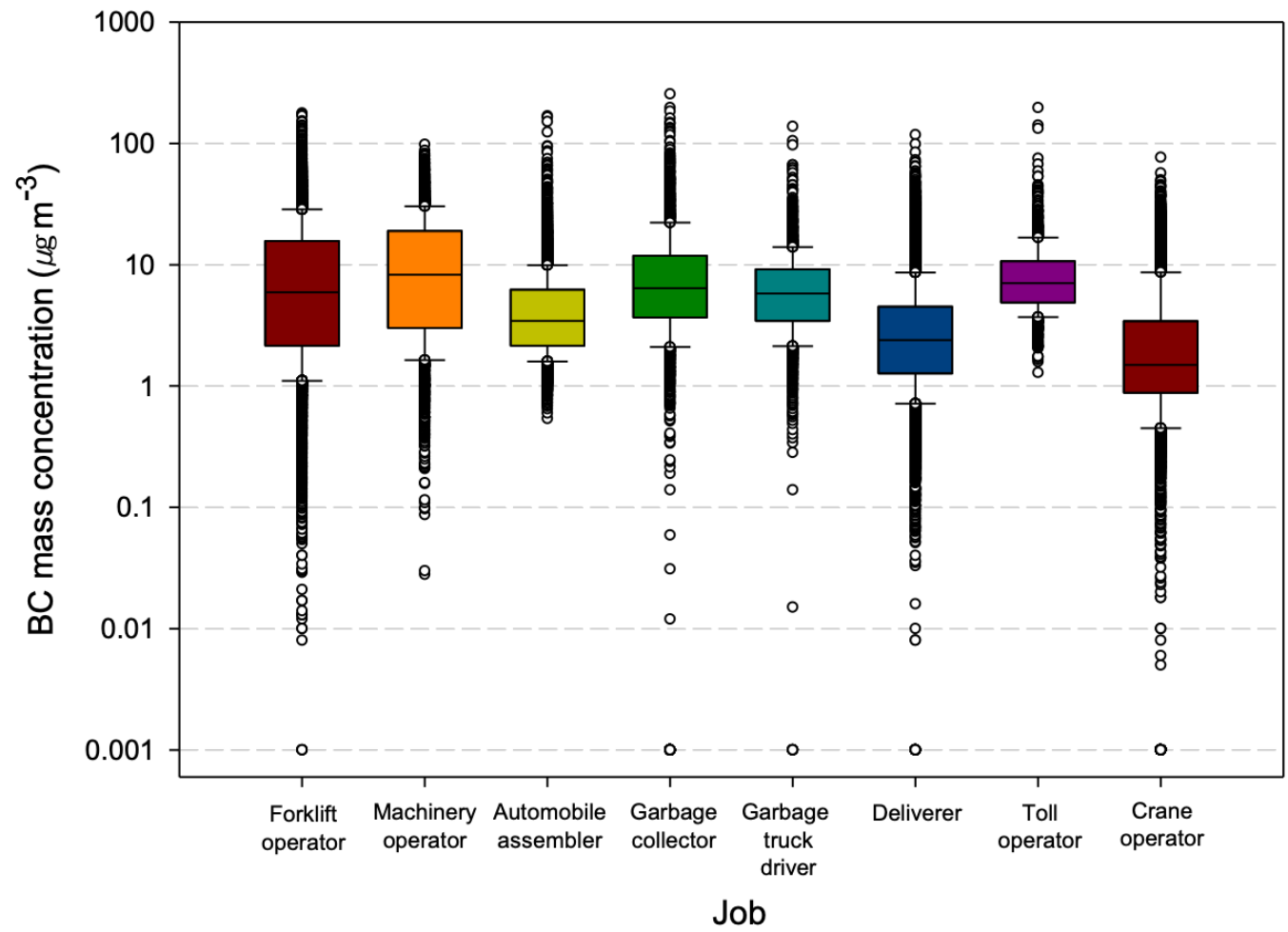

Fig. 2. Distribution of black carbon mass concentration levels among jobs. 
and other operations. Our review indicated that BC exposure can be worse when diesel-powered vehicles and equipment are used in indoor workplaces with an insufficient level of ventilation.

Though toll operators work outdoors without directly operating diesel engine equipment, the average $B C$ exposure level $\left(A M=9.5 \mu \mathrm{g} \mathrm{m}^{-3}, \mathrm{GM}=7.5 \mu \mathrm{g} \mathrm{m}^{-3}\right)$ was higher than that of automobile assemblers $\left(A M=5.2 \mu \mathrm{g} \mathrm{m}^{-3}, \mathrm{GM}=3.8 \mu \mathrm{g} \mathrm{m}^{-3}\right.$ ) who were operating diesel engine cars indoors. Toll operators working at highway tollbooth are repeatedly exposed to vehicle emission due to the acceleration of the automobiles while leaving the tollbooth. In addition, tollbooth windows remain open for most of the working hours (Fig. S1(d)). A study done by Shin et al. (2021) comparing the BC concentration at the same time inside and outside the tollbooth showed that the GM concentration of BC inside booth $\left(7.3 \mu \mathrm{g} \mathrm{m}^{-3}\right)$ was $88 \%$ of the outside concentration $\left(8.3 \mu \mathrm{g} \mathrm{m}^{-3}\right)$. BellocSantaliestra et al. (2015) measured the polycyclic aromatic hydrocarbons and found no clear difference between concentrations in and outside the tollbooth. In this study, the toll operator's $B C$ exposure distribution showed the smallest variation (GSD $=1.9$ ) compared to other occupations (Table 2 and Fig. 2). Therefore, it is necessary to supply filtered fresh air to the inside of the tollbooth to maintain positive pressure or to minimize the toll operator's exposure to vehicle exhaust pollutants using an automatic window.

For automobile assemblers, the main source of exposure to $B C$ is when a finished vehicle is started and moved or inspected. Therefore, in this study, we investigated the pre-delivery inspection workers working at the final stage of the assembly line. Major inspection tasks include checking engine parts, exterior and interior part, vehicle wheel alignment, brake test, and driving tests. All diesel vehicles produced at the passenger car manufacturing sites surveyed in 2017 were equipped with DPF and manufactured in accordance with EURO 6 standards. Thus, at the end of the manufacturing process, though many cars were started and inspected, the BC exposure level of automobile assemblers was very low (Table 2 and Fig. 2).

\subsection{BC Exposure Characteristics by Task}

$\mathrm{BC}$ exposure according to the type of activity performed within each job varied. The distribution of $\mathrm{BC}$ mass concentrations by tasks within job are indicated in Table 2 and Fig. 3.

In general, activities performed inside the workplace, such as driving a forklift $\left(A M=14.7 \mu \mathrm{g} \mathrm{m}^{-3}\right.$, $\left.\mathrm{GM}=9.5 \mu \mathrm{g} \mathrm{m}^{-3}\right)$ and machinery operation near an operational forklift $\left(\mathrm{AM}=13.0 \mu \mathrm{g} \mathrm{m}^{-3}, \mathrm{GM}=\right.$ $7.4 \mu \mathrm{g} \mathrm{m}^{-3}$ ), were found to be mainly higher than those monitored outdoors ( $\mathrm{AM}=7.9 \mu \mathrm{g} \mathrm{m}^{-3}$, $\mathrm{GM}=4.4 \mu \mathrm{g} \mathrm{m}^{-3}$ ). In addition, $\mathrm{BC}$ exposure levels were high when working close to the diesel engine emission point. The workers involved in the collection of household waste using diesel trucks (garbage collector: $\mathrm{AM}=10.7 \mu \mathrm{g} \mathrm{m}^{-3}, \mathrm{GM}=5.5 \mu \mathrm{g} \mathrm{m}^{-3}$; garbage truck driver: $\mathrm{AM}=7.5 \mu \mathrm{g} \mathrm{m}^{-3}$, $\mathrm{GM}=5.5 \mu \mathrm{g} \mathrm{m}^{-3}$ ) and toll operators $\left(\mathrm{AM}=9.5 \mu \mathrm{g} \mathrm{m}^{-3}, \mathrm{GM}=7.5 \mu \mathrm{g} \mathrm{m}^{-3}\right.$ ) were found to be exposed to far higher $B C$ concentrations than delivery workers $\left(A M=3.9 \mu \mathrm{g} \mathrm{m}^{-3}, \mathrm{GM}=2.4 \mu \mathrm{g} \mathrm{m}^{-3}\right.$ ) and crane operators $\left(<3.0 \mu \mathrm{g} \mathrm{m}^{-3}\right)$.

Garbage collectors had the highest $\mathrm{BC}$ exposure level while collecting and dumping garbage $\left(A M=11.2 \mu \mathrm{g} \mathrm{m}^{-3}, \mathrm{GM}=5.4 \mu \mathrm{g} \mathrm{m}^{-3}\right)$, followed by riding in the back of a truck $\left(A M=9.5 \mu \mathrm{g} \mathrm{m}^{-3}\right.$, $\mathrm{GM}=6.3 \mu \mathrm{g} \mathrm{m}^{-3}$ ). Garbage truck drivers also had a higher level of BC exposure while assisting with garbage collection and dumping $\left(A M=11.1 \mu \mathrm{g} \mathrm{m}^{-3}, \mathrm{GM}=7.0 \mu \mathrm{g} \mathrm{m}^{-3}\right)$ than while driving inside the vehicle $\left(A M=7.2 \mu \mathrm{g} \mathrm{m}^{-3}, \mathrm{GM}=5.4 \mu \mathrm{g} \mathrm{m}^{-3}\right)$. A garbage truck is usually manned by two collectors and a driver. Garbage collectors pick up household wastes from each collection point, and dump them into a garbage container of the truck. In addition, they remain around the engine tailpipe and frequently ride upon a step at the rear of the truck to facilitate exiting the vehicle at its frequent stops for picking up household waste (Fig. S1(b)), which results in elevated BC exposure. Garbage truck drivers mainly stay inside vehicles, unless they are required to perform a collector's tasks (e.g., pick-up/dumping).

Deliverers load the products in their vehicle at distribution warehouses (Fig. S1(c)) and deliver products from door to door. Because the income of deliverers is determined by the quantity of the courier, they often do not turn off the car between each delivery to deliver large quantities as quickly as possible. Therefore, it is estimated that the BC exposure level is low as the deliverer is exposed to the engine exhaust for only a short period of time while unloading packages.

Crane operators operate a gantry crane to unload a container from a ship at port or use a transfer crane or a tractor in yard (Fig. S1(e)). Gantry cranes are powered by electric power, and transfer cranes and tractors are powered by diesel engines. In particular, the exhaust vents of 


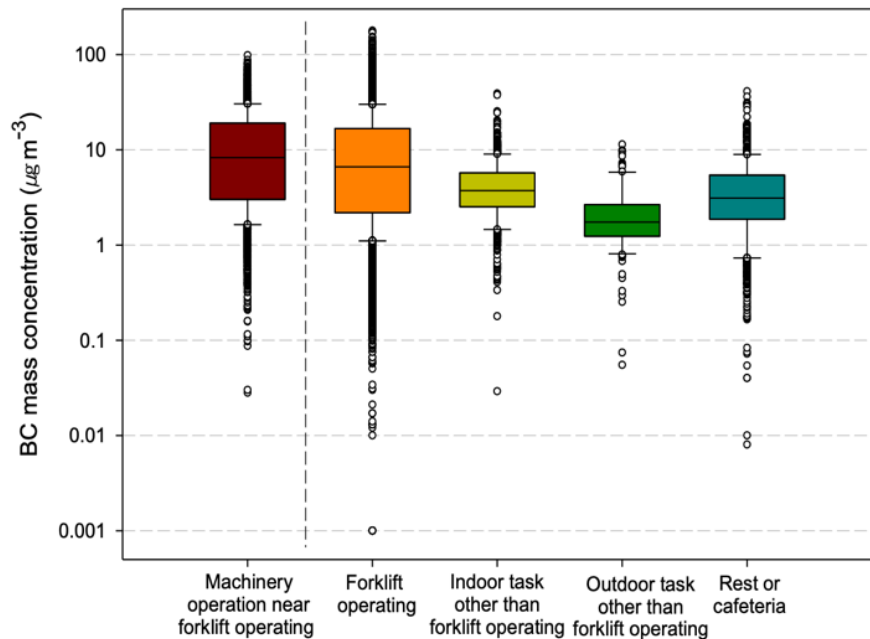

(a) Machinery operator/forklift operator

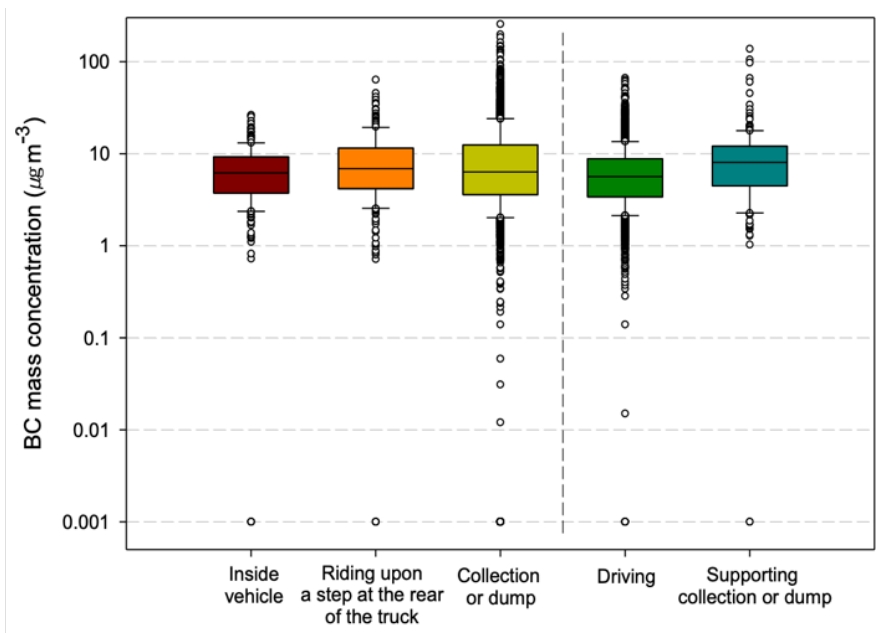

(c) Garbage collector/garbage truck driver

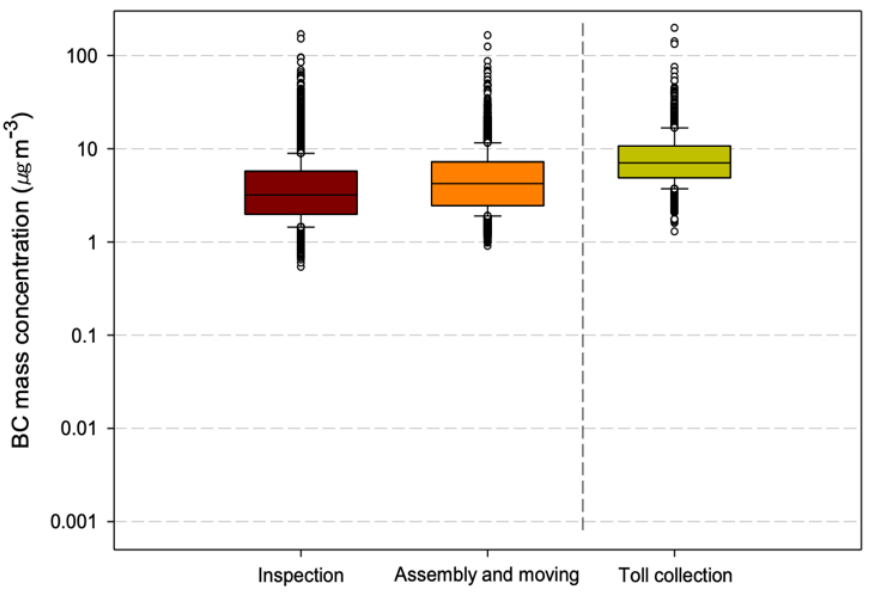

(b) Automobile assembler/toll operator

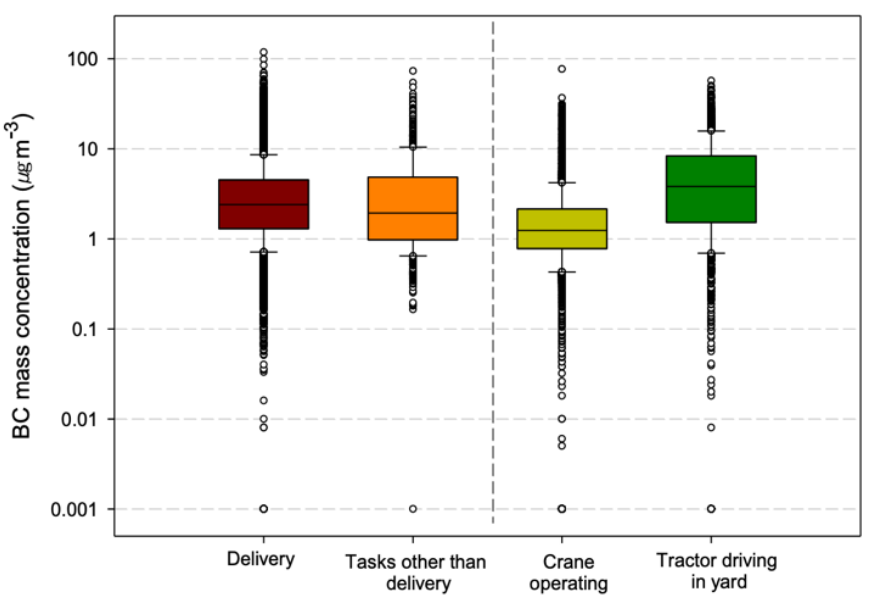

(d) Deliverer/crane operator

Fig. 3. Distribution of black carbon mass concentration levels by tasks. A dash line separates the two job groups.

the tractor are close to the height of the driver's seat (Fig. S1(e)), increasing the risk of exposure to $B C$ when driving the tractor. Therefore, the average exposure level of $B C$ was approximately three times higher when driving a tractor in yard $\left(A M=6.4 \mu \mathrm{g} \mathrm{m}^{-3}\right)$ than when operating a crane $\left(A M=2.2 \mu \mathrm{g} \mathrm{m}^{-3}\right)$ (Fig. 3(d)).

\subsection{Major Determinants Affecting BC Exposure Level}

BC exposure levels for each of the four determinants, namely operation of diesel engine vehicle, proximity to source of black carbon, workplace, and work type, showed significant differences as a result of a linear mixed model that considers the random effect of workers and dates nested within a job and with fixed effects of four determinants and their pairwise interaction terms $(p<$ 0.001) (Fig. 4). In particular, the average exposure level of BC was approximately twice as high when working near diesel engine equipment $\left(\mathrm{AM}=7.9 \mu \mathrm{g} \mathrm{m}^{-3}\right)$ than when working at a far distance $\left(\mathrm{AM}=4.1 \mu \mathrm{g} \mathrm{m}^{-3}\right)$.

Fig. 5 shows the comparison of BC mass concentration levels for 10 exposure groups (EGs) made by combination of four exposure determinants. The theoretical total combination of the four determinants was $16\left(2^{4}=16\right)$, but only 10 combinations were available for comparison in the exposure data of this study. Of the $10 \mathrm{EGs}$, the average $\mathrm{BC}$ exposure level of $\mathrm{EG} 1\left(\mathrm{AM}=10.7 \mu \mathrm{g} \mathrm{m}^{-3}\right.$, $\mathrm{GM}=6.1 \mu \mathrm{g} \mathrm{m}^{-3}$ ), working close to the DE source in a fixed location outdoors, without directly operating the diesel engine equipment was the highest. Garbage collection work and toll gate operator work are included in EG1. 


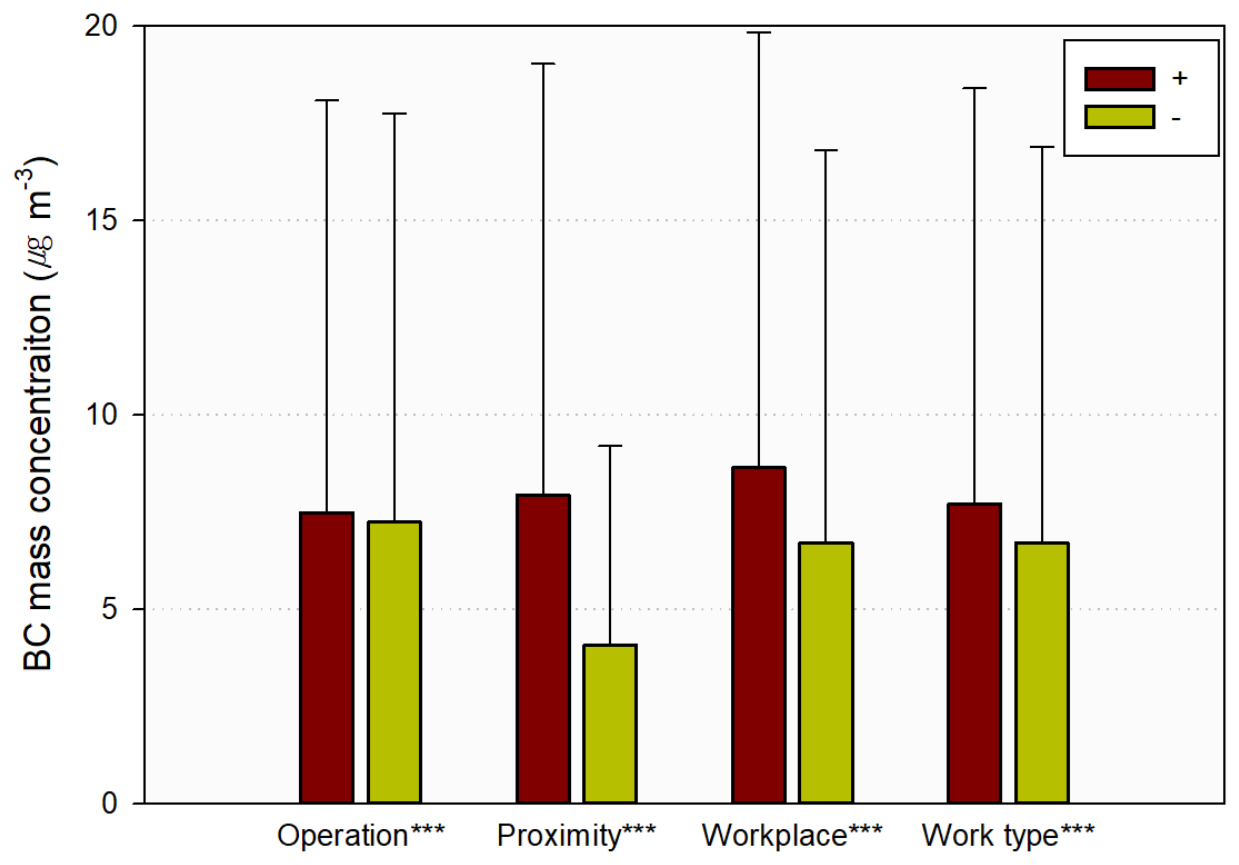

Fig. 4. Comparison of black carbon mass concentrations based on the four exposure determinants: operation of diesel engine vehicle (+: yes, -: no), proximity to source of black carbon (+: near, -: far), workplace (+: indoor, -: outdoor), and work type (+: moving work, -: stationary work). ${ }^{* * *}: p<$ $0.001 ; p$-value from a linear mixed model with random effects of workers and dates nested within a job and with fixed effects of operation, proximity, workplace, work type, and their pairwise interaction terms.

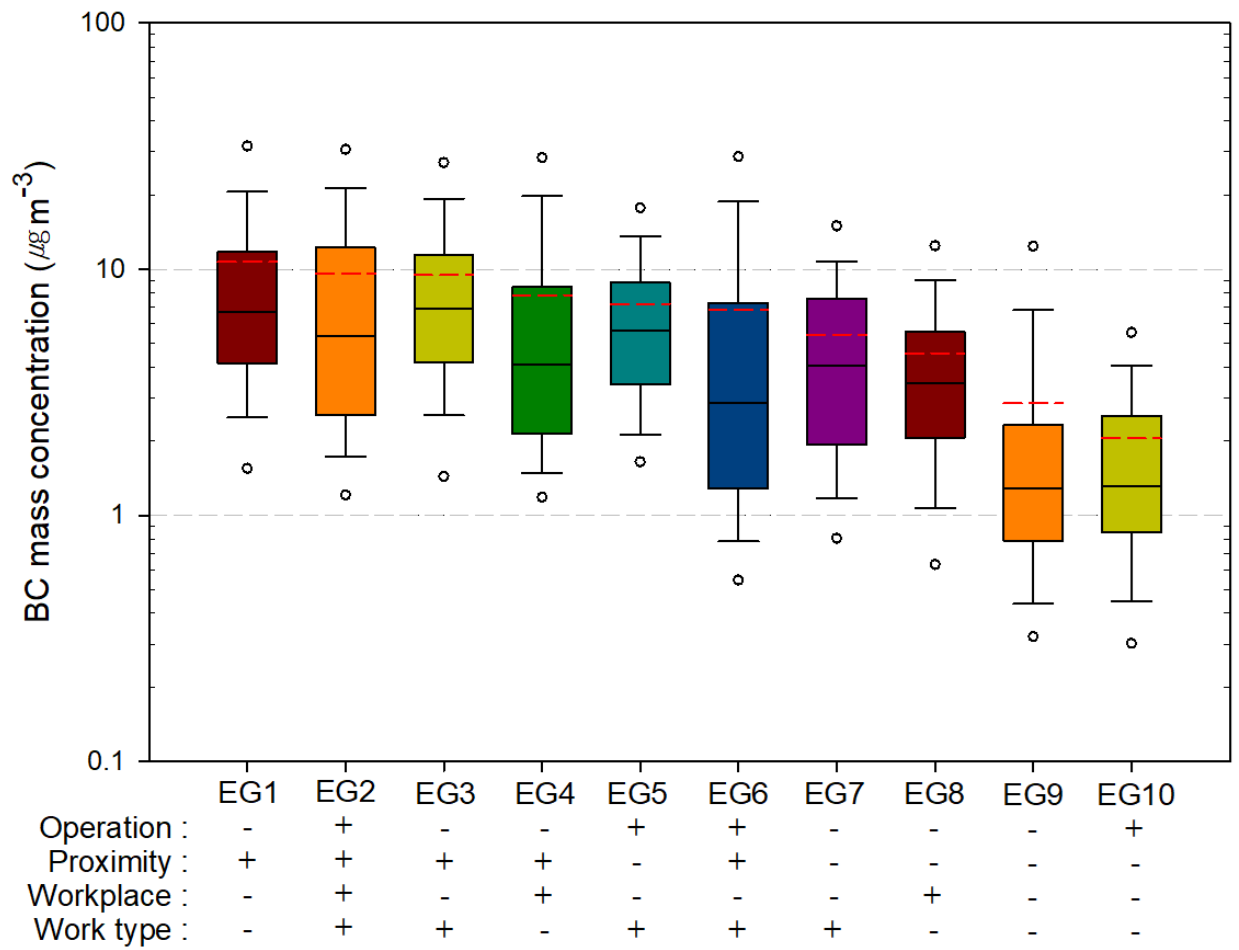

Fig. 5. Comparison of black carbon mass concentration levels between 10 exposure groups (EGs) based on the combination of four exposure determinants: operation of diesel engine vehicle (+: yes, -: no), proximity to source of black carbon (+: near, -: far), workplace (+: indoor, -: outdoor), and work type (+: moving work, -: stationary work). The dashed line within the box shows the arithmetic mean black carbon mass concentration. 
On the other hand, even if the diesel engine vehicle is operated directly, the $\mathrm{BC}$ exposure level of EG10, moving outdoors and working far from the source, was found to be the lowest $(\mathrm{AM}=$ $2.1 \mu \mathrm{g} \mathrm{m}^{-3}, \mathrm{GM}=1.2 \mu \mathrm{g} \mathrm{m}^{-3}$ ). The crane operators operating the diesel-powered transfer crane are included in EG10. There is an approximate fivefold difference between the lowest exposure group (EG10) and the highest exposure group (EG1). Our results show that increased proximity to diesel engine exhaust sources and indoor work are the main determinants of BC exposure levels. This finding is supported by Stapleton et al. (2018) and Sauvé et al. (2020). They analyzed farming activity and reported that $\mathrm{BC}$ exposure levels increased when close to diesel-powered equipment indoors. Farmers who used or worked near diesel vehicles were reported to be exposed to $\mathrm{GMs}$ of $\mathrm{BC}$ exposure ranging from $0.5 \mu \mathrm{g} \mathrm{m}^{-3}$ while harvesting to $4.9 \mu \mathrm{g} \mathrm{m}^{-3}$ during animal work. Higher GMs were found for increased proximity to diesel-fueled vehicles and equipment (2.9 vs. $0.3 \mu \mathrm{g} \mathrm{m}^{-3}$ ) (Stapleton et al., 2018). A 68\% increase in BC concentration was predicted when working near diesel-powered vehicles compared to far proximity (Sauvé et al., 2020).

\subsection{Other Factors Affecting BC Exposure Level}

It was found that $\mathrm{BC}$ exposure was significantly different according to the year of manufacture for diesel vehicles (Table 3) and EURO Stages by type of diesel vehicle (Table 4). However, there was no trend in the decline in $\mathrm{BC}$ exposure levels according to the diesel vehicle production year or EURO Stage. Taxell and Santonen (2017) argued that the characteristics of DE should be considered by dividing them into old or traditional diesel engines as well as into new technology diesel engines with multi-component emission reduction systems, including the DPF, according to the strengthening of the EU's DE emission regulations. In accordance with the Korea-EU Free Trade Agreement, the emission standards for new diesel-powered vehicles were lowered to meet EURO 6 in 2014 in Korea (MOE, 2020).

For diesel engine forklift operators, when working indoors, BC exposure levels were significantly lower when DPF was installed $\left(\mathrm{AM}=13.5 \mu \mathrm{g} \mathrm{m}^{-3}, \mathrm{SD}=9.1 \mu \mathrm{g} \mathrm{m}^{-3}\right)$ than when DPF was not installed $\left(A M=26.5 \mu \mathrm{g} \mathrm{m}^{-3}, \mathrm{SD}=21.3 \mu \mathrm{g} \mathrm{m}^{-3}\right.$ ) (Fig. 6). In the case of the forklifts investigated in this study, most of the forklifts manufactured after 2009 were equipped with DPF.

\section{CONCLUSIONS}

We investigated $\mathrm{BC}$ exposure in eight occupations across seven industries and found significant variations in the mean exposure between different types of jobs and tasks $(p<0.001)$, even within the same industry. The four potential determinants, viz., the operation of a diesel engine vehicle (yes or no), proximity to the source of BC (near or far), location of the workplace (indoor or outdoor), and type of work (moving or stationary), exhibited statistically significant differences in their associated levels of BC exposure after we had accounted for the random effects of the individual workers and working dates (evaluated per occupation) as well as the fixed effects of the determinants and their pairwise interaction terms $(p<0.001)$. In particular, working near instead of far from diesel engine equipment doubled the average level of exposure. Additionally, upon comparing different combinations of the determinants, we identified proximity to diesel exhaust sources and indoor working conditions as the main factors of BC exposure. Hence, installing diesel particulate filters on diesel engine vehicles effectively reduces exposure.

The present study is subject to certain limitations. For example, we only monitored the concentration of BC during specific periods of time (individual days or seasons); thus, the values we obtained may lead to an underestimation of the daily exposure if used for seasons or environments with additional sources, e.g., reinforced heating, or reduced ventilation. Furthermore, we were unable to evaluate the potential effects of meteorological conditions (Sapkota and Buckley, 2003), including the wind speed and direction, on outdoor exposure. Nevertheless, we successfully estimated the level of $B C$ exposure and identified the potential risk factors for specific types of jobs involving diesel vehicles.

Although these findings may not be applicable to other occupations that involve dieselpowered vehicles and equipment, e.g., heavy machinery operation, traffic policing, and parking enforcement, our results on the primary determinants may aid the development of a model capable of predicting the level of exposure for various types of work. 


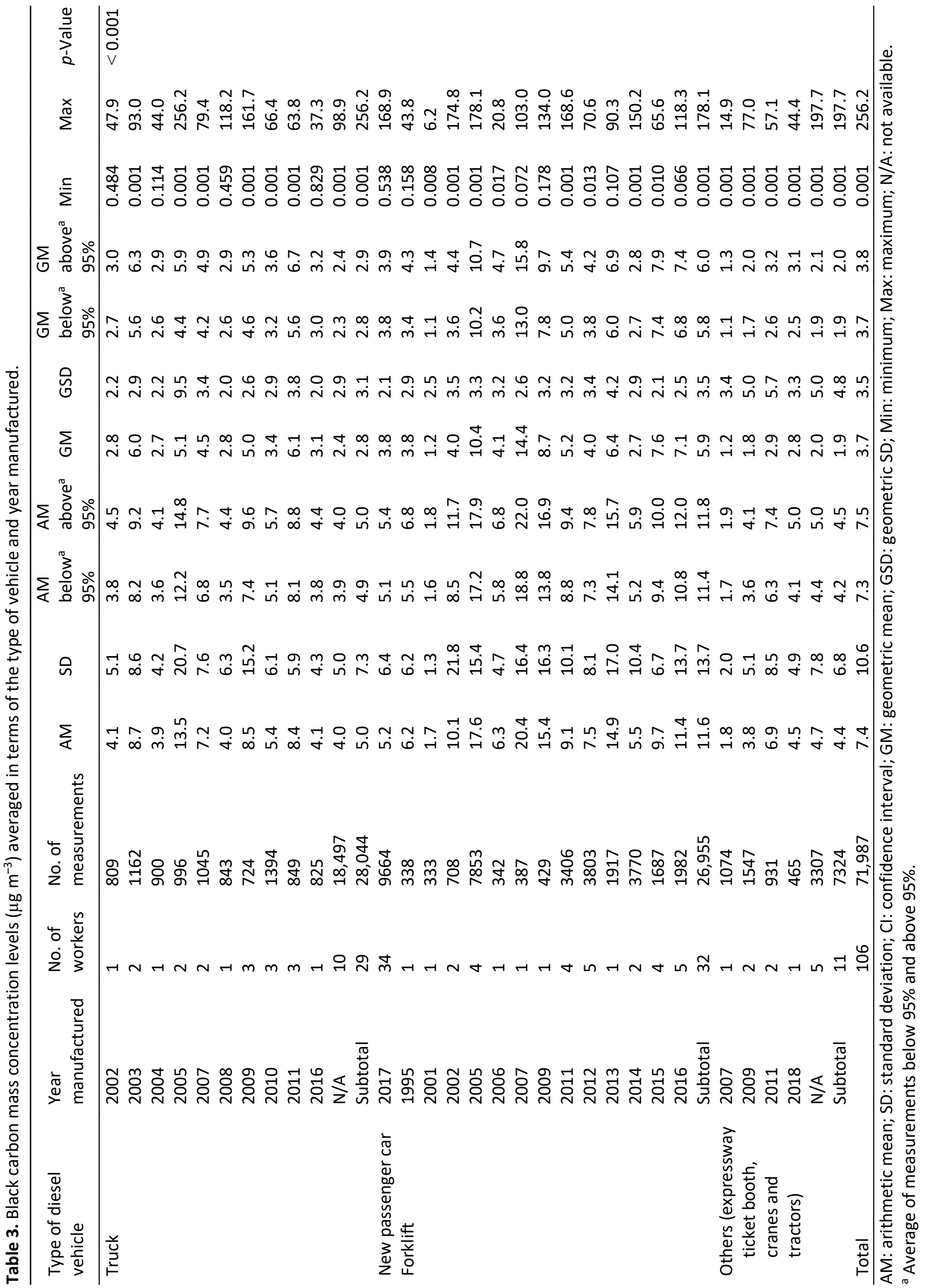




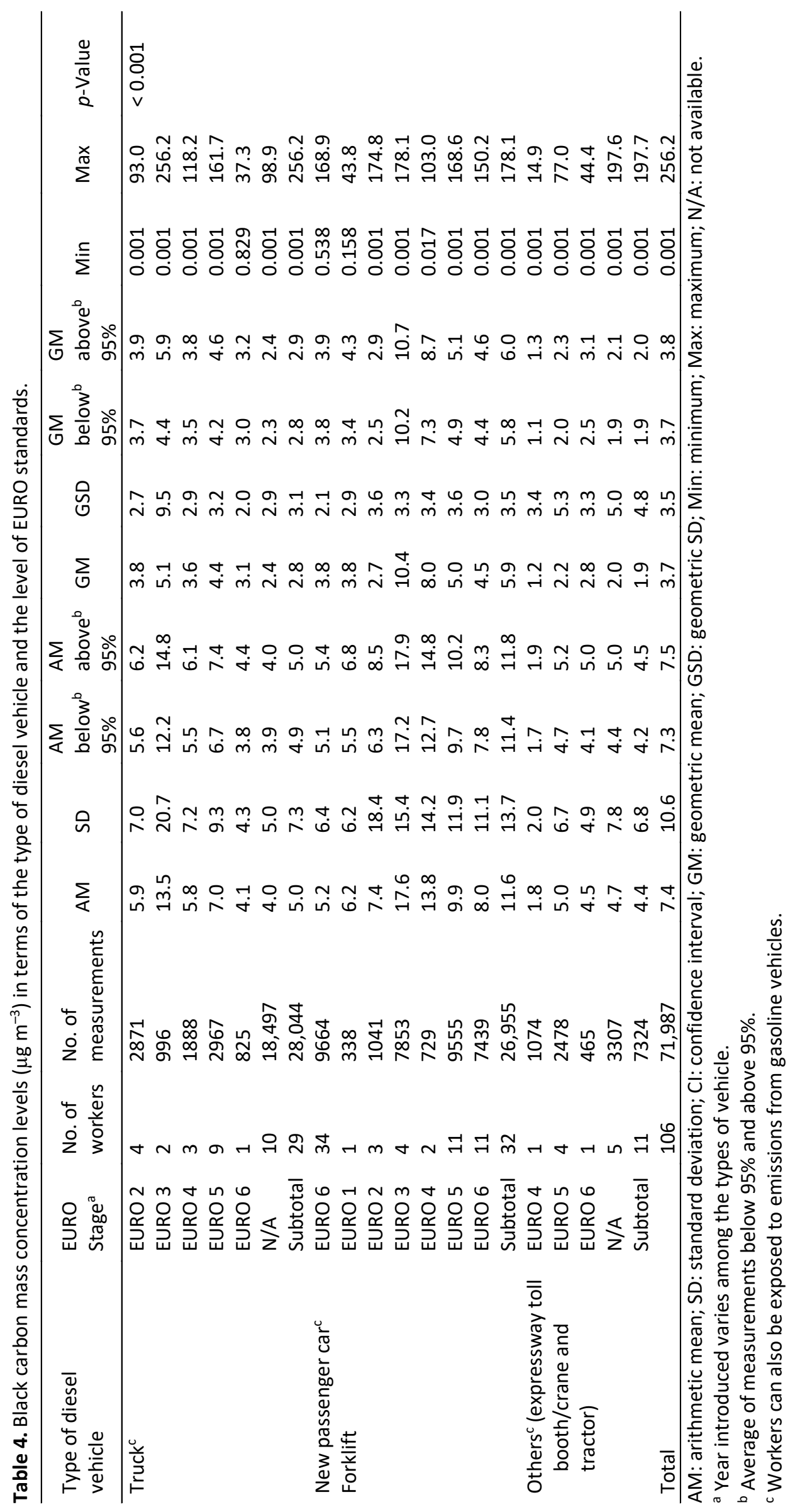




\section{SUPPLEMENTARY MATERIAL}

Supplementary material for this article can be found in the online version at https://doi. org/10.4209/aaqr.200675

\section{REFERENCES}

Anenberg, S.C., Schwartz, J., Shindell, D., Amann, M., Faluvegi, G., Klimont, Z., JanssensMaenhout, G., Pozzoli, L., Van Dingenen, R., Vignati, E., Emberson, L., Muller, N.Z., West, J.J., Williams, M., Demkine, V., Hicks, W.K., Kuylenstierna, J., Raes, F., Ramanathan, V. (2012). Global air quality and health co-benefits of mitigating near-term climate change through methane and black carbon emission controls. Environ. Health Perspect. 120, 831-839. https://doi.org/10.1289/ehp.1104301

Belloc-Santaliestra, M., van der Haar, R., Molinero-Ruiz, E. (2015). Occupational exposure assessment of highway toll station workers to vehicle engine exhaust. J. Occup. Environ. Hyg. 12, 51-61. https://doi.org/10.1080/15459624.2014. 935781

Cai, J., Yan, B., Ross, J., Zhang, D., Kinney, P.L., Perzanowski, M.S., Jung, K., Miller, R. and Chillrud, S.N. (2014). Validation of microAeth $\AA$ as a black carbon monitor for fixed-site measurement and optimization for personal exposure characterization. Aerosol Air Qual. Res. 14, 1-9. https://doi.org/10.4209/aaqr.2013.03.0088

Choi, S., Park, J.H., Kim, S.Y., Kwak, H., Kim, D., Lee, K.H., Park, D.U. (2019). Characteristics of PM2.5 and black carbon exposure among subway workers. Int. J. Environ. Res. Public Health 16, 2901. https://doi.org/10.3390/ijerph16162901

Dons, E., Panis, L.I., Van Poppel, M., Theunis, J., Willems, H., Torfs, R., Wets, G. (2011). Impact of time-activity patterns on personal exposure to black carbon. Atmos. Environ. 45, 3594-4602. https://doi.org/10.1016/j.atmosenv.2011.03.064

Galea, K.S., Mair, C., Alexander, C., de Vocht, F., van Tongeren, M. (2016). Occupational exposure to respirable dust, respirable crystalline silica and diesel engine exhaust emissions in the London tunnelling environment. Ann. Occup. Hyg. 60, 263-269. https://doi.org/10.1093/annh yg/mev067

Gong, T., Sun, Z., Zhang, X., Zhang, Y., Wang, S., Han, L., Zhao, D., Ding, D., Zheng, C. (2019) Associations of black carbon and $\mathrm{PM}_{2.5}$ with daily cardiovascular mortality in Beijing, China. Atmos. Environ. 214, 116876. https://doi.org/10.1016/j.atmosenv.2019.116876

Grahame, T.J., Klemm, R., Schlesinger, R.B. (2014). Public health and components of particulate matter: the changing assessment of black carbon. J. Air Waste Manage. Assoc. 64, 620-660. https://doi.org/10.1080/10962247.2014.912692

Health Effects Institute (HEI) (2010). Traffic-related air pollution: A critical review of the literature on emissions, exposure, and health effects. Panel on the Health Effects of Traffic-Related Air Pollution. https://www.healtheffects.org/publication/traffic-related-air-pollution-critical-reviewliterature-emissions-exposure-and-health (accessed 13 November 2020)

Hua, J., Yin, Y., Peng, L., Geng, F., Zhu, L. (2014). Acute effects of black carbon and PM 2.5 on children asthma admissions: a time-series study in a Chinese city. Sci. Total Environ. 481, 433438. https://doi.org/10.1016/j.scitotenv.2014.02.070

Janssen, N.A.H., Hoek, G., Simic-Lawson, M., Fischer, P., van Bree, L., ten Brink, H., Keuken, M., Atkinson, R.W., Ross Anderson H., Brunekreef, B., Cassee, F.R. (2011). Black carbon as an additional indicator of the adverse health effects of airborne particles compared with $\mathrm{PM}_{10}$ and $\mathrm{PM}_{2.5}$. Environ. Health Perspect. 119, 1691-1699. https://doi.org/10.1289/ehp.1003369

Korea Ministry of Environment (MOE) (2020). White Paper of Environment. Publication No. 111480000-000586-10 (In Korean). http://me.go.kr/ (accessed 13 November 2020).

Lee, J. (2019). Performance test of MicroAeth $\AA$ AE51 at concentrations lower than $2 \mu \mathrm{g} \mathrm{m}^{-3}$ in indoor laboratory. Appl. Sci. 9, 2766. https://doi.org/10.3390/app9132766

Lee, K.H., Jung, H.J., Park, D.U., Ryu, S.H., Kim, B., Ha, K.C., Kim, S., Yi, G., Yoon, C. (2015). Occupational exposure to diesel particulate matter in municipal household waste workers. PLoS One 10, e0135229. https://doi.org/10.1371/journal.pone.0135229

Lee, K.H., Jung, H.J., Shin, J.A., Kwak, H.S., Yi, G.Y., Ryu, S.H., Lee, K.M., Ha, K.C., Park, D.U. (2016). 
Characteristics of respirable elemental carbon (EC) exposures of household waste collectors. Aerosol Air Qual. Res. 16, 1000-1009. https://doi.org/10.4209/aaqr.2015.06.0414

McBean, E., Rovers, F. (1998). Statistical procedures for analysis of environmental monitoring data and risk assessment. Upper Saddle River, New Jersey, US: Prentice Hall.

Paunescu, A.C., Casas, M., Ferrero, A., Panella, P., Bougas, N., Beydon, N., Just, J., Lezmi, G., Sunyer, J., Ballester, F., Momas, I. (2019). Associations of black carbon with lung function and airway inflammation in schoolchildren. Environ. Int. 131, 104984. https://doi.org/10.1016/j.en vint.2019.104984

Sapkota, A., Buckley, T. (2003). The mobile source effect on curbside 1,3butadiene, benzene and particle bound polycyclic aromatic hydrocarbons assessed at a tollbooth. J. Air Waste Manage. Assoc. 53, 740-748. https://doi.org/10.1080/10473289.2003.10466212

Sauvé, J.F., Stapleton, E.M., O'Shaughnessy, P.T., Locke, S.J., Josse, P.R., Altmaier, R.W., Silverman, D.T., Liu, D., Albert, P.S., Beane Freeman, L.E., Hofmann, J.N., Thorne, P.S., Jones, R.R., Friesen, M.C. (2020). Diesel exhaust exposure during farming activities: Statistical modelling of continuous black carbon concentrations. Ann. Work Exposures Health 64, 503-513. https://doi.org/10.1093/annweh/wxaa032

Shakya, K.M., Rupakheti, M., Aryal, K., Peltier, R.E. (2016). Respiratory effects of high levels of particulate exposure in a cohort of traffic police in Kathmandu, Nepal. J. Occup. Environ. Med. 58, e218-e225. https://doi.org/10.1097/JOM.0000000000000753

Shin, J., Kim, B., Lee, J., Jung, J.S., Shin, Y.C., Lee, K. (2021). Exposure assessment of elemental carbon, ultrafine particles, and crystalline silica at highway toll booths. Environ. Eng. Res. 26, 200380. https://doi.org/10.4491/eer.2020.380

Stapleton, E.M., O'Shaughnessy, P.T., Locke, S.J., Altmaier, R.W., Hofmann, J.N., Beane Freeman, L.E., Thorne, P.S., Jones, R.R., Friesen, M.C. (2018). A task-based analysis of black carbon exposure in lowa farmers during harvest. J. Occup. Environ. Hyg. 15, 293-304. https://doi.org/ 10.1080/15459624.2017.1422870

Steinle, S., Reis, S., Sabel, C.E. (2013). Quantifying human exposure to air pollution-Moving from static monitoring to spatio-temporally resolved personal exposure assessment. Sci. Total Environ. 443, 184-193. https://doi.org/10.1016/j.scitotenv.2012.10.098

Suglia, S.F., Gryparis, A., Schwartz, J., Wright, R.J. (2008). Association between traffic related black carbon exposure and lung function among urban women. Environ. Health Perspect. 116, 3331337. https://doi.org/10.1289/ehp.11223

Taxell, P., Santonen, T. (2017). Diesel engine exhaust: Basis for occupational exposure limit value. Toxicol. Sci. 158, 243-251. https://doi.org/10.1093/toxsci/kfx110

United States Environmental Protection Agency (U.S. EPA) (2012). Chapter 4. Emissions of black carbon. In Report to congress on black carbon. pp. 85-114. Report No. EPA-450/R-12-001. https://19january2017snapshot.epa.gov/www3/airquality/blackcarbon/2012report/fullrepor t.pdf (accessed 13 November 2020).

Vilcassim, M.R., Thurston, G.D., Peltier, R.E., Gordon, T. (2014). Black carbon and particulate matter $\left(\mathrm{PM}_{2.5}\right)$ concentrations in New York City's subway stations. Environ. Sci. Technol. 48, 14738-14745. https://doi.org/10.1021/es504295h

World Health Organization (WHO) (2012). Health effects of black carbon. World Health Organization, Copenhagen, Denmark. https://www.euro.who.int/_data/assets/pdf_file/000 4/162535/e96541.pdf

Yang, H.H., Dhital, N.B., Wang, L.C., Hsieh, Y.S., Lee, K.T., Hsu, Y.T., Huang, S.C. (2019). Chemical characterization of fine particulate matter in gasoline and diesel vehicle exhaust. Aerosol Air Qual. Res. 19, 1439-1449. https://doi.org/10.4209/aaqr.2019.04.0191

Zanobetti, A., Coull, B.A., Gryparis, A., Kloog, I., Sparrow, D., Vokonas, P.S., Wright, R.O., Gold, D.R., Schwartz, J. (2013). Associations between arrhythmia episodes and temporally and spatially resolved black carbon and particulate matter in elderly patients. Occup. Environ. Med. 71, 201-207. https://doi.org/10.1136/oemed-2013-101526 